\title{
Hydrolytic enzyme activities in agricultural and forest soils. Some implications for their use as indicators of soil quality
}

\author{
C. Trasar-Cepeda ${ }^{\mathrm{a}, *}$, M.C. Leirós ${ }^{\mathrm{b}}$, F. Gil-Sotres ${ }^{\mathrm{b}}$ \\ a Departamento de Bioquímica del Suelo, Instituto de Investigaciones Agrobiológicas de Galicia, CSIC, Apartado 122, E-15780 Santiago de Compostela, Spain \\ ${ }^{\mathrm{b}}$ Departamento de Edafología y Química Agrícola, Facultad de Farmacia, Universidad de Santiago de Compostela, E-15782 Santiago de Compostela, Spain
}

\section{A R T I C L E I N F O}

\section{Article history:}

Received 18 October 2007

Received in revised form 27 March 2008

Accepted 31 March 2008

Available online $\mathrm{xxx}$

\section{Keywords:}

Soil enzymes

Soil use

Soil quality

Reforested soils

Agricultural soils

Galician soils

\begin{abstract}
A B S T R A C T
Although a great deal of information exists about the effect of land use on soil enzyme activities, much of this is contradictory and brings into question the suitability of soil enzyme activities as indicators of how land use affects soil quality. The purpose of this study was to investigate the effect of land use on different soil biochemical properties, especially hydrolytic enzyme activities, with the aim of providing knowledge about the problems related to the use of enzymes as indicators of soil quality. The data presented derive from various studies in which a large number of soils under different types of forest or agricultural management were analysed by the same methods. All of the soil samples were characterized in terms of their main physical and chemical properties, the activity of several hydrolases, microbial biomass $C$ and soil basal respiration. The results indicate that soil use causes a large reduction in organic matter content and that the effect on enzyme activity varies depending on the type of land use or management and the type of enzyme. Furthermore, the enzyme activities per carbon unit (specific activities) in soils affected by land use are almost always higher than in maximum quality soils (climax soils under oak vegetation or oak soils), and land use also generates greater increases in the specific activity as the $\mathrm{C}$ content decreases. The mechanism responsible for these increases probably involves loss of the most labile organic matter. Enzyme enrichment is not always produced to the same degree, as it varies as a function of the enzyme and the type of land use under consideration. It is concluded that the complexity of the behaviour of the soil enzymes raises doubts about the use of enzyme activities as indicators of soil degradation brought about by land use.
\end{abstract}

(c) 2008 Elsevier Ltd. All rights reserved.

\section{Introduction}

Agricultural and forest misuse are some of the main causes of soil degradation (Dick, 1992; Lal et al., 1998). Soil preparation and tillage, fertilization, the use of machinery and harvesting all affect the soil environment and can cause a progressive loss of soil quality. At present, the quality of a soil is defined not only in terms of its productive capacity, but also takes into consideration that the soil forms an integral part of the ecosystem. Consequently, even when soil productivity has to be maximized, environmental effects must be kept to a minimum (Doran and Parkin 1994; Gregorich et al., 1994). It is thus evident that the changes in soil quality caused by different types of land use must first be quantified in order to establish the most sustainable types of use and management that also cause the least disturbance to the soil.

Given that soil quality depends on the physical, chemical, biological and biochemical properties of the soil, changes in these properties must be taken into account in assessing changes in soil

\footnotetext{
* Corresponding author. Tel.: +34 981 590958x270; fax: +34 981592504.

E-mail address: ctrasar@cesga.es (C. Trasar-Cepeda).
}

quality (Klein et al., 1985; Yakovchenko et al., 1996). However, as changes in some soil properties may occur very slowly or may only occur when the soil undergoes drastic changes, such properties are not suitable for estimating soil quality (Filip, 2002), and properties that respond rapidly to environmental stress must be used (Dalal, 1998). Soil biological and biochemical properties do respond rapidly (Klein et al., 1985; Nannipieri et al., 1990), and include properties that are directly related to the number and activity of the soil microbiota (microbial biomass, basal respiration, etc.) as well as properties associated with the decomposition of organic compounds present in soils and the release of nutrients, i.e., the activity of hydrolytic enzymes (Visser and Parkinson, 1992; Gil-Sotres et al. 2005). Since enzymatic activity is highly sensitive to external agents and is relatively inexpensive and easy to determine, measurement of the activity of numerous hydrolytic enzymes has been widely used in recent years to study the effect of changes in soil use on processes that affect the cycling of bio-elements: C, N, P and S (Bandick and Dick, 1999; Dick et al., 1994; Kandeler and Eder, 1993). However, despite the profusion of information, the results obtained by different researchers are often contradictory, both as regards the effect of different agricultural practices and also the 
changes that the different enzyme activities have (Dick, 1992; Gil-Sotres et al., 2005).

Various authors have pointed out that ploughing causes an increase in biochemical activity in agricultural soils due to the exposure of new surfaces as soil aggregates are broken up (Dick, 1984; Khan, 1996; Latif et al., 1992; McGill et al., 1986), while others have reported a decrease in enzyme activities due to the decrease in organic matter content as a result of the mixing of horizons by ploughing (Carter, 1986; Dick, 1994; Jensen et al., 1996). The application of mineral and organic fertilizers has also been reported to have contrary effects in these soils. Some authors state that the use of organic fertilizers increases the biochemical activity of the soil due to the associated input of organic materials and microorganisms (Dick et al., 1988; Jenkinson, 1990; Kandeler et al., 1999), whereas others state that the activity decreases, particularly when poor quality manure is used (García et al., 1992; Perucci et al., 1984; Schipper and Sparling, 2000). Regarding inorganic fertilizers, although it is often considered that the presence of readily available inorganic nutrients inhibits enzyme synthesis in soil (Dick, 1992; Olander and Vitousek, 2000), some authors consider that the same presence may increase the biochemical activity of a soil by stimulating plant growth and the secretion of enzymes by roots (Lynch and Panting, 1980). Furthermore, there is no agreement about the effects caused by different management practices in soils under pasture. Thus, grass cutting may stimulate soil biochemical activity due to the resulting increase in the amount of dead roots (Holland, 1995; Mawdsley and Bardgett, 1997), or may decrease this activity due to the decrease in root exudates (Northup et al., 1999), or may have no effect at all on soil biochemical properties (Kuzyakov et al., 2002; Wardle and Barker, 1997). Similar contradictory effects have been cited in discussion of the effect on soils of the presence of grazing animals. Thus, some authors have indicated that grazing may cause an increase in biochemical activity due to the presence of the animals' excreta (Haynes and Williams, 1999; Zacheis et al., 2002), and others that it may cause a decrease in biochemical activity, usually attributed to degradation of the soil structure by trampling (Cao et al., 2004; Conant et al., 2001).

Forest soils are generally subject to fewer treatments than agricultural soils and more consistent effects may be expected; however, the information available is also contradictory. Thus, some authors have indicated that mechanized preparation of soil before reforestation, which involves the use of heavy machinery, may decrease the biochemical activity of the soil due to soil compaction (Nuñez-Regueira et al., 2006; Zinn et al., 2002), whereas others have indicated that the activity will be increased due to closer contact between microorganisms and the organic matter as a result of the compaction (Resck et al., 2000).

It is thus clear that land use does not always modify biochemical properties in the same way, and furthermore no biochemical property can be used as a universal indicator to demonstrate the effects of use, although properties such as biomass- $C$, and urease and $\beta$-glucosidase activities, are those usually used as possible indicators of the effects of land use on soil (Gil-Sotres et al., 2005).

There are different possible explanations for the lack of standard patterns of biochemical activity, particularly enzymatic activities, in response to soil use and management. One possibility is that these differences are due to a lack of standardized protocols for determining biochemical properties, which implies that the lack of consistent results is caused by methodological differences. Another reason for the contradictory results may be the small number of soils that are usually analysed in each study. Biochemical properties usually display a high degree of both spatial and temporal variability, and therefore a large number of samples may be required to overcome the statistical uncertainty, and this does not always occur. Another possible explanation for the random response of biochemical properties to soil use and management is the small number of enzyme activities that are usually analysed, and it is not uncommon to find studies in which only one enzyme activity is measured. Thus conclusions are reached about the type of variation suffered by soil enzymes, even though the behaviour of a single enzyme does not necessarily reflect the responses of other enzymes, as enzymes associated with different cycles and that participate in different stages of degradation will not necessarily respond in the same way (Sinsabaugh et al., 1991; Trasar-Cepeda et al., 2007). There is also a problem related to the lack of agreement about which kind of soils represent maximum quality and therefore can be used as reference soils with which to compare soils affected by use (Gil-Sotres et al., 2005). Two different options are usually considered: on one hand that maximum quality soils are represented by natural soils developed under climax vegetation (local potential vegetation) and that have not suffered any type of human interference (Fedoroff, 1987; Rasmussen et al., 1989; Trasar-Cepeda et al., 1998), and on the other, that maximum quality soils are highly productive soils that cause the least environmental impact (Doran et al., 1994; Jackson, 2002). Finally, it is also possible that the different behaviour in response to soil use and management may be because the activities of hydrolytic enzymes are not good indicators of soil quality and their potential usefulness in assessing soil quality may have been overestimated.

Our research group has spent many years investigating the activity of several hydrolytic enzymes in soils from Galicia (NW Spain), an Atlantic region with a humid climate (mean annual temperature between 12 and $15{ }^{\circ} \mathrm{C}$ and annual rainfall between 1000 and $1700 \mathrm{~mm}$ ). In our studies we have used the same analytical methods and have studied both forest soils under climax (or local potential) vegetation of Atlantic oakwood (oak soils), and soils under different types of forest or agricultural management. It is important to emphasize that of the two options introduced above, we have always considered that natural soils developed under local potential vegetation are the soils of maximum quality, and are therefore those that should display the greatest degree of equilibrium among all properties (Gil-Sotres et al., 2005; Trasar-Cepeda et al., 1998). On the other hand, it is also assumed that soil use will alter that equilibrium, and that this modification will be reflected in the behaviour of soil biochemical properties.

The overall objective of the present study was to provide information about the activity of different hydrolytic enzymes in soils subject to different types of use, with the aim of providing further knowledge about the problems related to the use of enzymes as indicators of soil quality. For each type of use, a large number of soils from Galicia (NW Spain) were analysed. The relative homogeneity in the conditions of formation of Galician soils and the use of the same protocols to analyse each biochemical property, enable comparison of the data obtained in the different studies.

\section{Materials and methods}

\subsection{Soils}

A total of 234 soils dedicated to different types of use were analysed. Of these, 40 were Umbrisols (ISSS Working Group R.B., 1998) developed under local potential vegetation of Atlantic oak (Quercus robur L.). These, because of their stability and lack of human influence, are considered the soils of highest biochemical quality in the region (Trasar-Cepeda et al., 1998) and, therefore, those used as reference soils to demonstrate the effects of land use on the soil biochemical properties. These soils (oak soils) were sampled at the start of autumn, before leaf fall, a time of year during which it has been observed that the values of the biochemical properties reflect the annual mean (Trasar-Cepeda et al., 2003). The biochemical properties of these soils have already been reported (Leirós et al., 2000; Trasar-Cepeda et al. 
2000). In addition, 78 soils (Umbrisols) from repopulated forests were studied, 35 from stands predominated by Eucalyptus globulus Labill (stands always of more than 20 years old) and 43 by pine trees, mainly Pinus pinaster Aiton (stands of more than 25 years old). All of these soils under forest were sampled at the beginning of autumn, at similar times to when the oak soils were sampled. The study also included 56 grassland soils, management of which usually involves organic fertilization (mainly with cattle slurry and sometimes pig manure) and occasional applications of inorganic fertilization (nitrogen and phosphorus), occasional presence of grazing animals and several harvests throughout the year. These grassland soils are either Umbrisols or, in topographically depressed areas, Gleysols, and were sampled at the end of the winter, before the soil preparations typically carried out in spring, as they are usually fertilized at the beginning of autumn to favour autumn growth of pasture (Piñeiro and González, 2002). Finally, 60 agricultural soils were also analysed, of which 45 (generally Umbrisols) were cropped soils under maize, and represented agricultural soils subject to traditional practices involving little mechanization, bi or tri annual rotation of crops (potato, rape, maize) and fertilization, mainly with manure. The samples of maize soils were collected after the crop was harvested and before the soil was tilled (i.e., during late autumn as the maize is collected in October-November), to avoid any interference from the effect of machinery or recent application of fertilizers and pesticides. The other 15 agricultural soils were Regosols collected from vineyards. These were strongly degraded, generally man-made soils on steep slopes that form terraces. These soils are usually strongly ploughed, fertilized with inorganic and organic fertilizers and are usually treated with fungicides several times throughout the year to avoid fungal diseases, which spread rapidly due to the high humidity in the region. The soil samples were collected in February, when no work is carried out in the vineyards, as it was necessary to leave a certain amount of time between grape harvesting (beginning of autumn) and collection of soil samples, to minimize the effects on the soil caused by the grape pickers and machinery during harvesting. The results corresponding to the agricultural soils have already been published (Miguéns et al., 2007; TrasarCepeda et al., 2008).

\subsection{Soil sampling}

The soils were collected after removal of the litter layer in the forest soils, the very dense layer of roots in the grassland soils and harvesting remains (where present) in the maize and vineyard soils. In all cases between 15 and 20 sub-samples of the upper soil horizon $(0-10 \mathrm{~cm})$ were collected and pooled in the field, transported in isothermal bags to the laboratory and then sieved through a $4 \mathrm{~mm}$ sieve. The samples were stored at $4{ }^{\circ} \mathrm{C}$ until analysis of the biochemical properties, always within 15 days; a sub-sample (approximately $500 \mathrm{~g}$ ) of the soil was air dried for analysis of the general properties and when the protocol required, part of the sub-samples (approximately $100 \mathrm{~g}$ ) were finely ground before analysis.

\subsection{Soil physical and chemical properties}

Total organic $\mathrm{C}$ (wet oxidation) and $\mathrm{N}$ (Kjeldahl digestion) contents and $\mathrm{pH}$ in $1 \mathrm{M} \mathrm{KCl}$ (1:2.5 soil:solution ratio) were determined following the methods described by Guitián-Ojea and Carballas (1976). Available P was extracted with $0.5 \mathrm{M}$ sodium bicarbonate ( $\mathrm{pH} 8.2$ ), according to Bowman and Cole (1978), and inorganic $\mathrm{P}$ in the extracts was determined according to Murphy and Riley (1962). Amorphous Al and Fe were extracted with $0.2 \mathrm{M}$ ammonium oxalate/oxalic acid buffer of pH 3.0 (McKeague and Day,
1966) and were determined by atomic absorption spectrometry. Particle size distribution was determined with a Robinson pipette and with Calgon as dispersant (Guitián-Ojea and Carballas, 1976).

\subsection{Microbial biomass carbon and basal respiration}

Microbial biomass $\mathrm{C}$ (Biomass $\mathrm{C}$ ) was determined by the chloroform fumigation-extraction method, with $0.5 \mathrm{M} \mathrm{K}_{2} \mathrm{SO}_{4}$ as extractant (Vance et al., 1987). The organic C of extracts was estimated by oxidation with potassium dichromate (Vance et al., 1987). The difference in C content of the fumigated and unfumigated extracts was converted to microbial biomass $C$ (expressed in $\mathrm{mg} \mathrm{kg}{ }^{-1}$ of dry soil) by applying a factor $\left(K_{\mathrm{c}}\right)$ of 0.45 (Jenkinson, 1988).

Soil basal respiration (Respiration) was determined by static incubation (Guitián-Ojea and Carballas, 1976). The $\mathrm{CO}_{2}$ produced during a 10-day period by $25 \mathrm{~g}$ soil samples incubated at field moisture content at $25^{\circ} \mathrm{C}$ was collected in $10 \mathrm{ml}$ of a $1 \mathrm{M} \mathrm{NaOH}$ solution, which was then titrated against $\mathrm{HCl}$ with an automatic titrator. The results are expressed as $\mathrm{mg} \mathrm{CO} 2-\mathrm{C} \mathrm{kg}^{-1} 10 \mathrm{~d}^{-1}$, and the metabolic coefficient or $q \mathrm{CO}_{2}\left(\mu \mathrm{g} \mathrm{CO}_{2}-\mathrm{C}\right.$ released $\mathrm{mg}^{-1}$ biomass carbon $\mathrm{h}^{-1}$ ) was calculated as the ratio between basal respiration and microbial biomass $\mathrm{C}$.

\subsection{Enzymatic activities}

Acid phosphomonoesterase (Monoester), $\beta$-glucosidase (Glucosid), phosphodiesterase (Diester) and arylsulphatase (Sulph) activities were determined after incubation of the soils with a substrate containing a $p$-nitrophenyl moiety and measurement of the amount of $p$-nitrophenol liberated during enzymatic hydrolysis, by spectrophotometry. The enzymatic activities were quantified by reference to calibration curves corresponding to $p$-nitrophenol standards incubated with each soil under the same conditions as for the samples, and the activities are expressed as $\mu \mathrm{mol}$ $p$-nitrophenol $g^{-1} h^{-1}$. Acid phosphomonoesterase activity was determined by using $16 \mathrm{mM} p$-nitrophenyl phosphate as substrate and incubating at pH 5.0 (Modified Universal Buffer, Skujins et al., 1962) and $37^{\circ} \mathrm{C}$. After $30 \mathrm{~min} 2 \mathrm{M} \mathrm{CaCl}_{2}$ was added and the liberated $p$-nitrophenol was extracted with $0.2 \mathrm{M} \mathrm{NaOH}$ (Tabatabai and Bremner, 1969, with the modifications indicated by Saá et al., 1993). Activity of $\beta$-glucosidase was determined as described for phosphomonoesterase activity except that the substrate was $25 \mathrm{mM}$ $p$-nitrophenyl- $\beta$-D-glucopyranoside, the incubation time was $1 \mathrm{~h}$ and the released $p$-nitrophenol was extracted with $0.1 \mathrm{M}$ (Trishydroxymethyl-aminomethane)- $\mathrm{NaOH}$ (THAM-NaOH) of $\mathrm{pH} 12$ (Eivazi and Tabatabai, 1988). Phosphodiesterase activity was measured by incubating soil samples with $10 \mathrm{mM}$ bis-p-nitrophenyl phosphate as substrate, at pH 5.0 (0.05 M THAM buffer) and $37{ }^{\circ} \mathrm{C}$ for $1 \mathrm{~h}$. After the incubation, $2 \mathrm{M} \mathrm{CaCl}_{2}$ was added and the released p-nitrophenol was extracted with $0.1 \mathrm{M}$ THAM-NaOH of $\mathrm{pH} 12$ (Bowman and Tabatabai, 1978). Arylsulphatase activity was determined with $5 \mathrm{mM} p$-nitrophenyl sulphate as substrate, with $0.5 \mathrm{M}$ acetate buffer ( $\mathrm{pH} 5.8$ ) and incubating for $1 \mathrm{~h}$ (Tabatabai and Bremner, 1970).

The activities of urease, and protease hydrolysing benzoylargininamide (BAA-protease, BAA-P) were determined as described by Nannipieri et al. (1980). Briefly, urease activity was determined using $1065.6 \mathrm{mM}$ urea as substrate, incubating for $1.5 \mathrm{~h}$ in $0.2 \mathrm{M}$ phosphate buffer ( $\mathrm{pH} 8.0$ ), and measuring the $\mathrm{NH}_{4}^{+}$released with an ammonia electrode. The BAA-protease activity was determined using the same incubation conditions and the same method for determining $\mathrm{NH}_{4}^{+}$, but with $30 \mathrm{mM} \alpha-N$-benzoyl-L-argininamide (BAA) as substrate. In both cases, enzyme activity is expressed as $\mu \mathrm{mol} \mathrm{NH}_{3} \mathrm{~g}^{-1} \mathrm{~h}^{-1}$. The activity of protease hydrolysing casein (casein-protease, Casein-P) was determined with $1 \%$ casein as 
substrate, incubating for $2 \mathrm{~h}$ in $0.05 \mathrm{M}$ Tris-hydroxymethylaminomethane- $\mathrm{HCl}$ (Tris- $\mathrm{HCl})$ buffer $(\mathrm{pH} \mathrm{9.0)}$ and the released amino acids determined by the Folin-Ciocalteu colorimetric method described by Ladd and Butler (1972), modified by Nannipieri et al. (1979). Enzyme activity is expressed as $\mu \mathrm{mol}$ tyrosine $\mathrm{g}^{-1} \mathrm{~h}^{-1}$.

Invertase activity was determined with $35.06 \mathrm{mM}$ sucrose as substrate, incubating for $3 \mathrm{~h}$, with $2 \mathrm{M}$ acetate buffer ( $\mathrm{pH}$ 5.5), and the released reducing sugars determined following the method of Schinner and von Mersi (1990). Carboxymethyl-cellulase (Cellulase) activity was determined similarly, except that the substrate was $0.7 \%$ carboxymethyl-cellulose and the incubation time was $24 \mathrm{~h}$ (Schinner and von Mersi, 1990). In both cases, the enzyme activities are expressed as $\mu \mathrm{mol}$ glucose $\mathrm{g}^{-1} \mathrm{~h}^{-1}$.

All determinations were performed in triplicate. The corresponding controls were carried out for each soil and enzyme activity by proceeding with the same analytical protocol described, but without the addition of the substrate at the moment of initiating the enzymatic reaction. For each soil sample the mean values of the three determinations (expressed on an oven-dried soil basis, $105^{\circ} \mathrm{C}$ ), were calculated.

\subsection{Statistical analysis}

For each property studied, the values in the tables are the minimum, maximum and mean values obtained for all soils subject to the same type of use. Statistical differences between mean values were determined by a Student's $t$-test [Statistica $6.0\left(\right.$ StatSoft $\left.^{\circledR}\right)$ for Windows].

\section{Results}

\subsection{Soil physical and chemical properties}

The soils under different uses and the oak soils were of similar texture (mainly sandy and sandy-loam), although the vineyard and maize soils contained more sand than the other soils (Table 1). In general, the soils were acidic and the values of $\mathrm{pH}$ in $\mathrm{KCl}$ showed how the soil use resulted in increased $\mathrm{pH}$, especially in the grassland and maize soils, in which the maximum value obtained was close to 7.0 (Table 1). The increase in $\mathrm{pH}$ was due to liming, which is common practice in Galicia, because the soils in the region are usually acidic or very acidic. Nevertheless all of the soils were still acidic, which suggests that the liming was not very intense. Soil use also caused an increase in the available inorganic $\mathrm{P}$ (Pi) content, particularly in the agricultural soils, which indicates intense phosphate fertilization. The increase in Pi was acute in the agricultural soils, and the mean concentrations of available $\mathrm{Pi}$ were 116 and $126 \mathrm{mg} \mathrm{kg}^{-1}$ in the vineyard and maize soils, respectively, and in both groups, the minimum concentration of available $\mathrm{Pi}$ was higher than the mean value obtained for the oak soils (Table 1 ).

Land use generated a noteworthy loss of organic matter, which affected both organic $\mathrm{C}$ and $\mathrm{N}$ content (Table 1 ). Thus, in the reforested soils the organic C content was between $60 \%$ and $70 \%$ that of the oak soils, and in the agricultural soils it was only between $10 \%$ and $40 \%$, with the lowest values corresponding to the vineyard soils. The decrease in nitrogen was not as marked, which indicates the effect of $\mathrm{N}$ fertilization. The reforested soils contained between $60 \%$ and $70 \%$ of the amount in the oak soils, whereas the agricultural soils contained between $20 \%$ and $60 \%$. The decrease in organic matter also causes a decrease in the content of extractable Fe and $\mathrm{Al}$ oxides (Table 1 ).

\subsection{Soil enzymatic activities: absolute values}

In the soils subject to the most intense agricultural use (the maize and vineyard soils) the values of the enzyme activities were always lower than in oak soils: in the maize soils, the enzyme activity was on average $42 \%$ of that in the oak soils, whereas in the vineyard soils, the activity was only $24 \%$ that in the oak soils (Table 2). In the reforested and grassland soils the values of the enzyme activities were lower, similar to, or even higher than those corresponding to the oak soils (Table 2 ). The mean values of activity and the ranges of variation obtained for the grassland soils were generally similar to those corresponding to the oak soils, whereas the differences were more acute in the reforested soils (Table 2).

For all of the carbon cycle enzymes, except invertase in the soils under eucalyptus (mean value $4.18 \mu$ mol glucose $\mathrm{g}^{-1} \mathrm{~h}^{-1}$ compared with $6.85 \mu \mathrm{mol}$ glucose $\mathrm{g}^{-1} \mathrm{~h}^{-1}$ for the oak soils), the activities of cellulase and invertase in the grassland and reforested soils were similar to those in the oak soils (Table 2). The mean values of $\beta$-glucosidase activity in soils under pine and eucalyptus (1.82 and $1.74 \mu \mathrm{mol} p$-nitrophenol $\mathrm{g}^{-1} \mathrm{~h}^{-1}$, respectively) were clearly higher, and those in grassland $\left(1.45 \mu \mathrm{mol} p\right.$-nitrophenol $\left.\mathrm{g}^{-1} \mathrm{~h}^{-1}\right)$ were slightly lower than the mean value obtained for oak soils $(1.55 \mu \mathrm{mol}$ p-nitrophenol $\mathrm{g}^{-1} \mathrm{~h}^{-1}$ ).

Regarding the nitrogen cycle enzymes, except urease in soils under eucalyptus ( $12.1 \mu \mathrm{mol} \mathrm{NH} \mathrm{g}^{-1} \mathrm{~h}^{-1}$ compared with $16.6 \mu \mathrm{mol}$ $\mathrm{NH}_{3} \mathrm{~g}^{-1} \mathrm{~h}^{-1}$ for the oak soils), the values of the three enzymes investigated were always similar or higher in the reforested and grassland soils than in oak soils (Table 2). The urease activity in pine soils was particularly high, and although the mean value of the activity was similar to that of the oak soils ( 16.9 and $16.6 \mu \mathrm{mol}$ $\mathrm{NH}_{3} \mathrm{~g}^{-1} \mathrm{~h}^{-1}$, respectively), the range of variation was much wider, and the maximum value of activity in the pine soils $(83.5 \mu \mathrm{mol}$ $\mathrm{NH}_{3} \mathrm{~g}^{-1} \mathrm{~h}^{-1}$ ) was almost double the maximum value in the oak soils $\left(49.8 \mu \mathrm{mol} \mathrm{NH}_{3} \mathrm{~g}^{-1} \mathrm{~h}^{-1}\right)$.

As regards the $\mathrm{P}$ cycle, in the grassland soils the activity of both enzymes was lower than in oak soils, taking into consideration the mean value of both activities and the range of variation

Table 1

Mean values and range of variation of the main properties, including some biochemical properties, of the soils under different types of use

\begin{tabular}{|c|c|c|c|c|c|c|c|c|c|c|c|c|}
\hline & \multicolumn{2}{|c|}{ Vineyard } & \multicolumn{2}{|l|}{ Maize } & \multicolumn{2}{|c|}{ Grassland } & \multicolumn{2}{|c|}{ Eucalyptus } & \multicolumn{2}{|l|}{ Pine } & \multicolumn{2}{|l|}{ Oak } \\
\hline & Mean & Range & Mean & Range & Mean & Range & Mean & Range & Mean & Range & Mean & Range \\
\hline$\overline{\mathrm{pH} \mathrm{KCl}}$ & $4.12^{*}$ & $3.58-4.96$ & $4.57^{*}$ & $3.84-6.97$ & $4.15^{*}$ & $3.40-5.50$ & $3.76^{*}$ & $3.15-4.29$ & $3.78^{*}$ & $2.91-5.71$ & 3.48 & $2.77-4.10$ \\
\hline Total C (\%) & $1.52^{*}$ & $0.43-2.98$ & $3.16^{*}$ & $1.47-6.35$ & $4.78^{*}$ & $1.80-11.52$ & $6.74^{*}$ & $2.17-11.81$ & $7.84^{*}$ & $1.74-11.79$ & 10.75 & $5.20-18.34$ \\
\hline Total N (\%) & $0.12^{*}$ & $0.03-0.21$ & $0.25^{*}$ & $0.14-0.52$ & $0.37^{*}$ & $0.15-0.95$ & $0.41^{*}$ & $0.11-0.87$ & $0.44^{*}$ & $0.10-0.71$ & 0.66 & $0.32-1.06$ \\
\hline $\mathrm{C} / \mathrm{N}$ & $13^{*}$ & $12-15$ & $12^{*}$ & 9-15 & $13^{*}$ & $10-18$ & 17 & $13-23$ & 18 & $11-24$ & 17 & $11-34$ \\
\hline Available $\mathrm{Pi}^{\mathrm{a}}$ & $116^{*}$ & $37-228$ & $126^{*}$ & $26-325$ & $39^{*}$ & $6-78$ & $9^{*}$ & $2-27$ & $8^{*}$ & $3-25$ & 20 & $8-47$ \\
\hline $\mathrm{Al}_{2} \mathrm{O}_{3}(\%)$ & $0.21^{*}$ & $0.08-0.32$ & $0.56^{*}$ & $0.15-1.63$ & $0.58^{*}$ & $0.07-2.16$ & 1.25 & $0.22-4.72$ & 1.19 & $0.27-3.23$ & 1.08 & $0.11-2.88$ \\
\hline $\mathrm{Fe}_{2} \mathrm{O}_{3}(\%)$ & $0.22^{*}$ & $0.04-0.67$ & $0.41^{*}$ & $0.16-0.94$ & $0.60^{*}$ & $0.11-2.22$ & $0.59^{*}$ & $0.16-1.34$ & $0.58^{*}$ & $0.13-1.24$ & 0.96 & $0.25-2.26$ \\
\hline Sand (\%) & $71^{*}$ & $64-79$ & $60^{*}$ & $29-74$ & 52 & $18-80$ & 52 & $26-78$ & 52 & $31-74$ & 51 & $13-80$ \\
\hline Clay (\%) & $12^{*}$ & $9-15$ & $15^{*}$ & $11-27$ & 20 & $9-43$ & 18 & $10-34$ & 18 & $9-26$ & 20 & $7-32$ \\
\hline
\end{tabular}

For each row, the asterisk $\left(^{*}\right)$ indicates that the mean value differs significantly $(P \leq 0.01)$ from that corresponding to the oak soils

a Inorganic $\mathrm{P}$, in $\mathrm{mg} \mathrm{kg}^{-1}$. 
Table 2

Mean values and range of variation of the enzymatic activities of the soils under different types of use

\begin{tabular}{|c|c|c|c|c|c|c|c|c|c|c|c|c|}
\hline & \multicolumn{2}{|c|}{ Vineyard } & \multicolumn{2}{|l|}{ Maize } & \multicolumn{2}{|c|}{ Grassland } & \multicolumn{2}{|c|}{ Eucalyptus } & \multicolumn{2}{|l|}{ Pine } & \multicolumn{2}{|l|}{ Oak } \\
\hline & Mean & Range & Mean & Range & Mean & Range & Mean & Range & Mean & Range & Mean & Range \\
\hline Cellulase $^{\mathrm{a}}$ & $0.05^{*}$ & $0.01-0.10$ & $0.09^{*}$ & $0.02-0.28$ & 0.20 & $0.06-0.38$ & 0.24 & $0.09-0.44$ & 0.23 & $0.01-0.38$ & 0.23 & $0.06-0.47$ \\
\hline Glucosid $^{\mathrm{b}}$ & $0.45^{*}$ & $0.08-0.90$ & $0.72^{*}$ & $0.20-1.73$ & 1.45 & $0.45-3.09$ & 1.74 & $0.58-4.74$ & 1.82 & $0.48-5.37$ & 1.55 & $0.67-4.58$ \\
\hline Invertase $^{a}$ & $1.28^{*}$ & $0.16-2.92$ & $2.60^{*}$ & $0.39-6.01$ & 6.03 & $1.58-19.50$ & $4.18^{*}$ & $1.20-10.02$ & 6.16 & $1.99-11.57$ & 6.66 & $2.00-10.95$ \\
\hline Casein- $\mathrm{P}^{\mathrm{C}}$ & $0.29^{*}$ & $0.01-0.52$ & $0.73^{*}$ & $0.13-1.49$ & $1.23^{*}$ & $0.41-2.83$ & 1.04 & $0.47-2.04$ & $1.28^{*}$ & $0.48-2.00$ & 0.94 & $0.36-1.75$ \\
\hline BAA-P ${ }^{d}$ & $4.6^{*}$ & $1.3-10.2$ & $7.1^{*}$ & $1.0-14.1$ & 19.6 & $3.8-50.7$ & 15.7 & $4.8-32.7$ & 17.7 & $1.6-40.9$ & 15.3 & $2.7-34.3$ \\
\hline Urease $^{d}$ & $1.9^{*}$ & $0.4-3.2$ & $4.3^{*}$ & $1.6-12.9$ & 17.7 & $2.2-44.4$ & 12.1 & $3.5-31.6$ & 16.9 & $0.8-83.5$ & 16.6 & $3.2-49.8$ \\
\hline Diester $^{\mathrm{b}}$ & $1.22^{*}$ & $0.03-0.24$ & $0.32^{*}$ & $0.08-0.72$ & $0.64^{*}$ & $0.19-1.39$ & $1.62^{*}$ & $0.39-3.66$ & $1.58^{*}$ & $0.33-3.19$ & 0.96 & $0.30-2.69$ \\
\hline Monoester $^{\mathrm{b}}$ & $0.12^{*}$ & $0.24-1.92$ & $2.58^{*}$ & $0.61-7.11$ & $4.86^{*}$ & $1.53-9.69$ & 7.45 & $1.05-16.33$ & 7.43 & $1.20-13.58$ & 6.62 & $2.23-15.76$ \\
\hline Sulph ${ }^{\mathrm{b}}$ & $0.03^{*}$ & $0.00-0.07$ & $0.15^{*}$ & $0.02-0.40$ & 0.43 & $0.07-1.43$ & $0.28^{*}$ & $0.06-0.76$ & $0.31^{*}$ & $0.01-0.96$ & 0.46 & $0.07-0.91$ \\
\hline
\end{tabular}

For each row, the asterisk $(*)$ indicates that the mean value differs significantly $(P \leq 0.01)$ from that corresponding to the oak soils.

a $\mu$ mol glucose $\mathrm{g}^{-1} \mathrm{~h}^{-1}$

b $\mu \mathrm{mol} p$-nitrophenol g ${ }^{-1} \mathrm{~h}^{-1}$.

c $\mu \mathrm{mol}$ tyrosine $\mathrm{g}^{-1} \mathrm{~h}^{-1}$.

d $\mu \mathrm{mol} \mathrm{NH} \mathrm{N}^{-1} \mathrm{~h}^{-1}$.

(Table 2). In the reforested soils, the mean activities of both enzymes were always higher than in the oak soils (Table 2). Thus, for example, the mean values of phosphodiesterase activity in the soils under pine and eucalyptus (1.58 and $1.62 \mu \mathrm{mol} p$-nitrophenol $\mathrm{g}^{-1} \mathrm{~h}^{-1}$, respectively) were almost double the mean value $\left(0.96 \mu \mathrm{mol} p\right.$-nitrophenol $\left.\mathrm{g}^{-1} \mathrm{~h}^{-1}\right)$ obtained for oak soils, although there was little difference amongst these three groups of soils in terms of the range of variation in the values of this enzyme activity (Table 2). The mean values of phosphomonoesterase activity in eucalyptus and pine soils were somewhat higher than in oak soils. However, in the pine soils both the minimum and maximum values were lower than those in the oak soils, whereas in the soils under eucalyptus the minimum value was less than half that in the oak soils and the maximum value was somewhat higher (Table 2).

Finally, the values of the only sulphur cycle enzyme determined, arylsulphatase, were lower in the reforested than in the oak soils, especially in eucalyptus soils, while in the grassland soils the values of the activity (mean, maximum and minimum) were similar to those in the oak soils, although the maximum value was lower in the latter (Table 2).

\subsection{Soil enzymatic activities: values in relation to the total carbon content of the soils}

If we consider the values of enzymatic activity in relation to $C$, i.e., the enzymatic activity divided by the organic $C$ content for each of the soils (specific activity), we can see that in general the mean values for each group of soils (Table 3 ) were higher in the soils affected by human activity than in the oak soils. Exceptions to this were observed for cellulase and arylsulphatase, in which, except for the grassland soils (for which the values of the specific activity of both enzymes were more than double those in the oak soils) the mean values were almost the same in the soils affected by human use and in the oak soils (Table 3). For the remaining enzymes the differences were very large, particularly in the grassland soils (Table 3 ). Thus, for the $C$ cycle enzymes, the activities of $\beta$-glucosidase and invertase per unit of $C$ in grasslands were almost twice those in the oak soils, and in the other soils they were around one and a half times those in the oak soils, except in eucalyptus soils in which the value of specific invertase activity was similar to that in oak soils (Table 3).

As regards the nitrogen cycle enzymes, in the maize and vineyard soils, the values of specific urease activity were lower than in the oak soil, despite the fact that the minimum values in both groups of soils were double that in the latter soil (Table 3 ). In all other cases, the activities of the nitrogen cycle enzymes were almost two times higher in the grassland soils than in the oak soil, and one and a half times higher than in the other soils (Table 3).

For the P cycle enzymes, the highest values corresponded to the reforested and grassland soils, with values of specific activity of both enzymes approximately twice those corresponding to the oak soils, although in the pine soils this only applied to the mean values, as the maximum and minimum values were very similar to those corresponding to the oak soils (Table 3 ). For both phosphodiesterase and phosphomonoesterase, the activities per unit $\mathrm{C}$ in the vineyard and maize soils were similar to those in the oak soils (Table 3).

Table 3

Mean values and range of variation of the enzymatic activities per unit of $C$ in the soils under different types of use

\begin{tabular}{|c|c|c|c|c|c|c|c|c|c|c|c|c|}
\hline & \multicolumn{2}{|c|}{ Vineyard } & \multicolumn{2}{|l|}{ Maize } & \multicolumn{2}{|c|}{ Grassland } & \multicolumn{2}{|c|}{ Eucalyptus } & \multicolumn{2}{|l|}{ Pine } & \multicolumn{2}{|l|}{ Oak } \\
\hline & Mean & Range & Mean & Range & Mean & Range & Mean & Range & Mean & Range & Mean & Range \\
\hline Cellulase $/ \mathrm{C}^{\mathrm{a}}$ & 3.1 & $1.6-6.5$ & 2.9 & $1.0-9.5$ & $4.8^{*}$ & $1.6-15.7$ & $3.7^{*}$ & $1.2-6.1$ & $2.9^{*}$ & $0.7-5.2$ & 2.1 & $0.5-4.1$ \\
\hline Glucosid/C & $30^{*}$ & $8-64$ & $24^{*}$ & $8-49$ & $33^{*}$ & $8-114$ & $27^{*}$ & $10-85$ & $24^{*}$ & $8-60$ & 15 & $4-41$ \\
\hline Invertase $/ \mathrm{C}^{\mathrm{a}}$ & 84 & $37-157$ & $86^{*}$ & $9-165$ & $129 *$ & $45-275$ & 63 & $17-120$ & 82 & $38-169$ & 67 & $16-132$ \\
\hline Casein- $\mathrm{P} / \mathrm{C}^{\mathrm{C}}$ & $19^{*}$ & $3-29$ & $25^{*}$ & $6-63$ & $27^{*}$ & $11-54$ & $16^{*}$ & $8-32$ & $17^{*}$ & $6-35$ & 10 & $3-22$ \\
\hline $\mathrm{BAA}-\mathrm{P} / \mathrm{C}^{\mathrm{d}}$ & $317^{*}$ & $195-618$ & $227^{*}$ & $49-533$ & $435^{*}$ & $102-902$ & $236^{*}$ & $53-522$ & $219^{*}$ & $48-440$ & 148 & $26-306$ \\
\hline Urease $/ C^{d}$ & 123 & $68-175$ & 134 & $61-247$ & $381^{*}$ & $44-887$ & 178 & $46-384$ & 213 & $45-898$ & 159 & $31-641$ \\
\hline Diester/C $C^{b}$ & 8 & $5-11$ & 11 & $2-31$ & $14^{*}$ & $7-49$ & $26^{*}$ & $7-62$ & $20^{*}$ & $7-33$ & 9 & $2-22$ \\
\hline Monoester/C ${ }^{b}$ & 85 & $33-159$ & 84 & $32-239$ & $110^{*}$ & $44-311$ & $115^{*}$ & $16-252$ & $107^{*}$ & 20-166 & 63 & $21-151$ \\
\hline Sulph $/ C^{b}$ & $1.8^{*}$ & $0.4-3.9$ & 4.8 & $0.4-8.8$ & $9.0^{*}$ & $2.2-23.8$ & 4.4 & $0.6-8.4$ & 4.0 & $0.1-10.4$ & 4.6 & $0.6-10.0$ \\
\hline
\end{tabular}

For each row, the asterisk $(*)$ indicates that the mean value differs significantly $(P \leq 0.01)$ from that corresponding to the oak soils.

a $\mu$ mol glucose $\mathrm{g}^{-1} \mathrm{Ch}^{-1}$.

b $\mu$ mol $p$-nitrophenol $\mathrm{g}^{-1} \mathrm{Ch}^{-1}$

c $\mu$ mol tyrosine $\mathrm{g}^{-1} \mathrm{Ch}^{-1}$.

d $\mu \mathrm{mol} \mathrm{NH} \mathrm{N}_{3} \mathrm{~g}^{-1} \mathrm{Ch}^{-1}$. 
Finally, the only S cycle enzyme investigated (arylsulphatase) showed similar specific activity in maize, pine, eucalyptus and oak soils, whereas in the vineyard soils the activity was less than half, and in the grassland soils it was approximately twice the activity observed in the other soils (Table 3 ).

\section{Discussion}

Although it is usually assumed that soil use results in decreased enzyme activity (Bandick and Dick, 1999; Dick, 1992; Dilly et al., 2003; Haynes and Tregurtha, 1999; Islam and Weil, 2000), the results obtained here indicate that for the large group of soils studied, this assumption is not correct, as a decrease was not found for all enzymes or for all types of land use. In fact, the enzyme activity associated with soil use varied depending on the type of land use and management, as well as on the type of enzyme, and the enzyme activity was lower than, the same as or higher than in the oak soils. However, the data obtained confirm that enzymes such as phosphomonoesterase, which are often reported to be inhibited by fertilization with phosphate fertilizers (Clarholm, 1993; Olander and Vitousek, 2000), did indeed display much lower activities in strongly fertilized soils with high contents of available Pi (Table 1), such as the maize, vineyard and, to a lesser extent, the grassland soils, than in the oak soils. A similar explanation may also be considered for the differences in sulphatase activity, the low values of which in the vineyard soils (Table 2) could be attributed to inhibition resulting from the addition of sulphate, as the fungicide usually used in vineyards is the Bordeaux mix, which contains copper sulphate, i.e. the typical feedback inhibition caused by the presence of the final product of an enzyme reaction (Lehninger, 1978). In contrast, in soils that received several applications throughout the year of cattle slurry, an organic fertilizer rich in readily decomposable nitrogen (Díaz-Fierros et al., 1988), such as the cropped soils, the nitrogen cycle enzymes show higher activities than in the oak soils (Table 2), which reflects the typical stimulation due to the presence of substrate (Lehninger, 1978).

The strong reduction in the organic matter content as a result of soil use makes comparison of the absolute values of the different enzyme activities difficult and does not allow a clear diagnosis of the effect of soil use on soil quality, as it is not possible to determine whether the observed modifications in the enzymatic activities are due to the lower content of organic matter in the soils or to real differences in enzymatic activity. One way of overcoming this difficulty and allowing comparison of soils under different types of use is to use the values of specific activity, i.e., the values of activity per unit of carbon (Barriuso et al., 1988). The use of this relationship reveals that in the soils affected by human activity the values of specific enzyme activities are generally higher than those in the oak soils. In other words, land use causes an important loss of organic matter (probably the most labile and less stabilized organic matter), with either a smaller decrease or an increase in the absolute enzyme activity, but these changes always result in a higher enzyme activity per unit of carbon, i.e., land use causes a relative increase in enzyme activity in the soil organic matter so that the greater the loss of organic matter caused by the intensity of soil management, the greater the enzymatic activity per unit of $\mathrm{C}$.

The above is remarkable and somewhat unexpected, as it was thought that a decrease in the soil organic matter content would be accompanied by a similar reduction in enzymatic activity. There are two possible explanations for this: the first is that land use generates stress in the microbiota, which responds with increased activity, therefore causing the observed enzyme enrichment (Doran, 1980). The second possibility is that this enrichment represents an ecological mechanism to retain soil metabolic activity (Burns, 1982), which is clearly at risk due to the progressive loss of organic matter, especially the most labile organic matter (Janzen et al., 1992; Ogle et al., 2005).

As regards the possibility that the increase in enzyme activity in soils under different types of use is due to the stress in the soil microbiota, it should be noted that the values of respiration and microbial biomass $\mathrm{C}$ were always lower in the agricultural and the forest soils than in the oak soils (Table 4). Furthermore, the reduction in respiration and in microbial biomass is always of the same order (Table 4). As a result, the mean values of $q \mathrm{CO}_{2}$ for the agricultural and reforested soils were very similar to each other and almost identical to the mean value obtained for the oak soils, although the mean value of this parameter in the vineyard soils was almost three times higher than in the other soils (Table 4), which according to Dalal (1998) and Haynes (1999) indicates that the vineyard soils are the only soils with a highly stressed microbiota. The fact that the $q \mathrm{CO}_{2}$ remained the same in the other soils (forest and agricultural) suggests that land use do not have a direct effect on the metabolic activity of the microorganisms, and that the microorganisms are not directly responsible for the observed increase in enzyme activity.

Given that the enzyme enrichment in the soils affected by use does not appear to be caused by accelerated metabolism of the soil microorganisms, it must be attributed to the second of the abovementioned possibilities, i.e., that this enrichment represents an ecological mechanism to retain soil metabolic activity. Although the data available does not allow us to determine the exact mechanism involved, two hypotheses can be suggested. On the one hand, the enrichment may result from the loss of labile organic matter from the soil, usually an organic matter with a low quantity of bound enzymes and whose loss would indirectly increase the proportion of enzymes in the remaining organic matter. On the other hand, the enrichment could be a result of a change in the capacity of the organic matter of soils affected by land use to retain soil enzymes by physical or chemical bonds.

The strong modification in the organic matter content that the soils undergo with use, does allow us to study how the increase in enzyme activity occurred as the carbon content decreased. To do this, we examined the distribution of soils within each land use in terms of carbon content. For each type of land use, the soils were grouped within six different ranges of C content: $0-2 \%, 2-5 \%, 5-8 \%$, $8-11 \%, 11-14 \%$ and more than $14 \%$ of the maximum $C$ content, as

Table 4

Mean values and range of variation of some biochemical properties of the soils under different types of use

\begin{tabular}{|c|c|c|c|c|c|c|c|c|c|c|c|c|}
\hline & \multicolumn{2}{|c|}{ Vineyard } & \multicolumn{2}{|l|}{ Maize } & \multicolumn{2}{|c|}{ Grassland } & \multicolumn{2}{|c|}{ Eucalyptus } & \multicolumn{2}{|l|}{ Pine } & \multicolumn{2}{|l|}{ Oak } \\
\hline & Mean & Range & Mean & Range & Mean & Range & Mean & Range & Mean & Range & Mean & Range \\
\hline Biomass $\mathrm{C}^{\mathrm{a}}$ & $49^{*}$ & $0-173$ & $201^{*}$ & $0-357$ & $493^{*}$ & $72-2003$ & $437^{*}$ & $88-952$ & $519^{*}$ & 197-993 & 781 & $250-1438$ \\
\hline Respiration $^{\mathrm{b}}$ & $72 *$ & $16-138$ & $161^{*}$ & $55-328$ & $358^{*}$ & $43-776$ & $268^{*}$ & $53-842$ & $342^{*}$ & $137-658$ & 615 & $340-1239$ \\
\hline$q \mathrm{CO}_{2}{ }^{\mathrm{c}}$ & $9.7^{*}$ & $0.0-30.9$ & 3.6 & $1.7-9.8$ & 3.4 & $1.0-7.4$ & 2.8 & $0.5-5.3$ & 3.0 & $0.9-7.6$ & 3.5 & $1.5-8.5$ \\
\hline
\end{tabular}

For each row, the asterisk $\left(^{*}\right)$ indicates that the mean value differs significantly $(P \leq 0.01)$ from that corresponding to the oak soils

a $\mathrm{mg} \mathrm{kg}^{-1}$

b $\mathrm{mg} \mathrm{CO}_{2}-\mathrm{C} \mathrm{kg}^{-1} 10 \mathrm{~d}^{-1}$

c $\mu \mathrm{g} \mathrm{CO} 2-\mathrm{C}$ mg Biomass $\mathrm{Ch}^{-1}$. 
found in some of the oak soils. If we consider the distribution of the soils in each group according to their total $C$ content, we can see that with increased management intensity, there is a decrease in the number of soils with high total $\mathrm{C}$ content and an increase in the soils with low C content (Fig. 1).

When we consider, for the same groups, the values of activity per unit of $C$, i.e., specific activity (Table 5), we can see that for the oak soils, some enzymes such as arylsulphatase and invertase show a very slight increase in the activity per unit of carbon as the $C$ content of the soils decreases. However, in general, there is a clear tendency towards similar values whatever the $C$ content of the soils (Table 5), which reveals the close relationship between the enzyme activities and the organic matter content, and allowed the concept of biochemical equilibrium to be defined for these soils developed under local potential vegetation in the absence of human influence (Trasar-Cepeda et al., 1998).

In contrast, for the soils affected by land use, it was observed that in general for all enzymes and types of use, there was a large increase in specific enzymatic activity, which shows that the lower the $C$ content of the soil, the greater the abundance of enzymes per unit of carbon, which is also observed for smaller ranges of $C$ than those present in the oak soils (Table 5). Thus, for the $C$ cycle enzymes, the increases in $\beta$-glucosidase and cellulase are very clear, particularly those for $\beta$-glucosidase and, for cellulase, those corresponding to the forest and grassland soils (Table 5). For the $\mathrm{N}$ cycle enzymes, the same behaviour was observed, with the values of activity per unit of carbon for both proteases being much higher than in the oak soils, particularly in the grassland soils and, to a lesser extent, in the soils under maize (Table 5). The two P-cycle enzymes behaved differently from each other. The specific activities of phosphodiesterase in the vineyard and maize soils were similar to those in the oak soils in which there was no enzyme enrichment, while in the grassland and forest soils they were much higher than in the oak soils. For phosphomonoesterase in the soils subject to land use, especially in the forest soils, the specific activity was much higher than in the oak soils (Table 5). For the S cycle enzyme, the specific activity in the maize and reforested soils is similar to that in the oak soils, in which there was no enzyme enrichment, whereas in the grassland soils the specific activity was much higher and in the vineyard soils much lower than in the oak soils (Table 5).

The observed increase in enzymatic activity per unit of $C$ in the soils affected by human influence suggests that organic matter is lost at a greater rate than is enzymatic activity. In other words, the relative increase in activity suggests that in soils affected by use, especially in cropped soils, although a large part of the soil organic matter is lost, there remains a pool of organic matter in which the hydrolytic enzymes have stabilized. This may be because it is the most labile organic matter that is lost and the most humified that remains (Nourbakhsh, 2007); the latter contains extracellular enzymes bound to humic or to clay-humic soil colloids. Binding of enzymes to humic colloids and clays is a mechanism that confers protection to the enzymes and contributes to maintaining a pool of relatively stable enzymes in the soil (Burns, 1978; Ladd and Butler, 1975; Nannipieri et al., 1980). A high hydrolytic potential may thus be maintained in the reforested and cultivated soils and the need for continual synthesis of enzymes avoided (Burns, 1982). Similar results were reported by Masciandaro and Ceccanti (1999), who observed that as the intensity of cultivation increased in soils in two different agro-ecosystems in the Mediterranean, both the absolute enzymatic activity and the carbon content of the soils decreased, but that the enzymatic activity suffered a process of stabilization linked to the presence of humic substances.
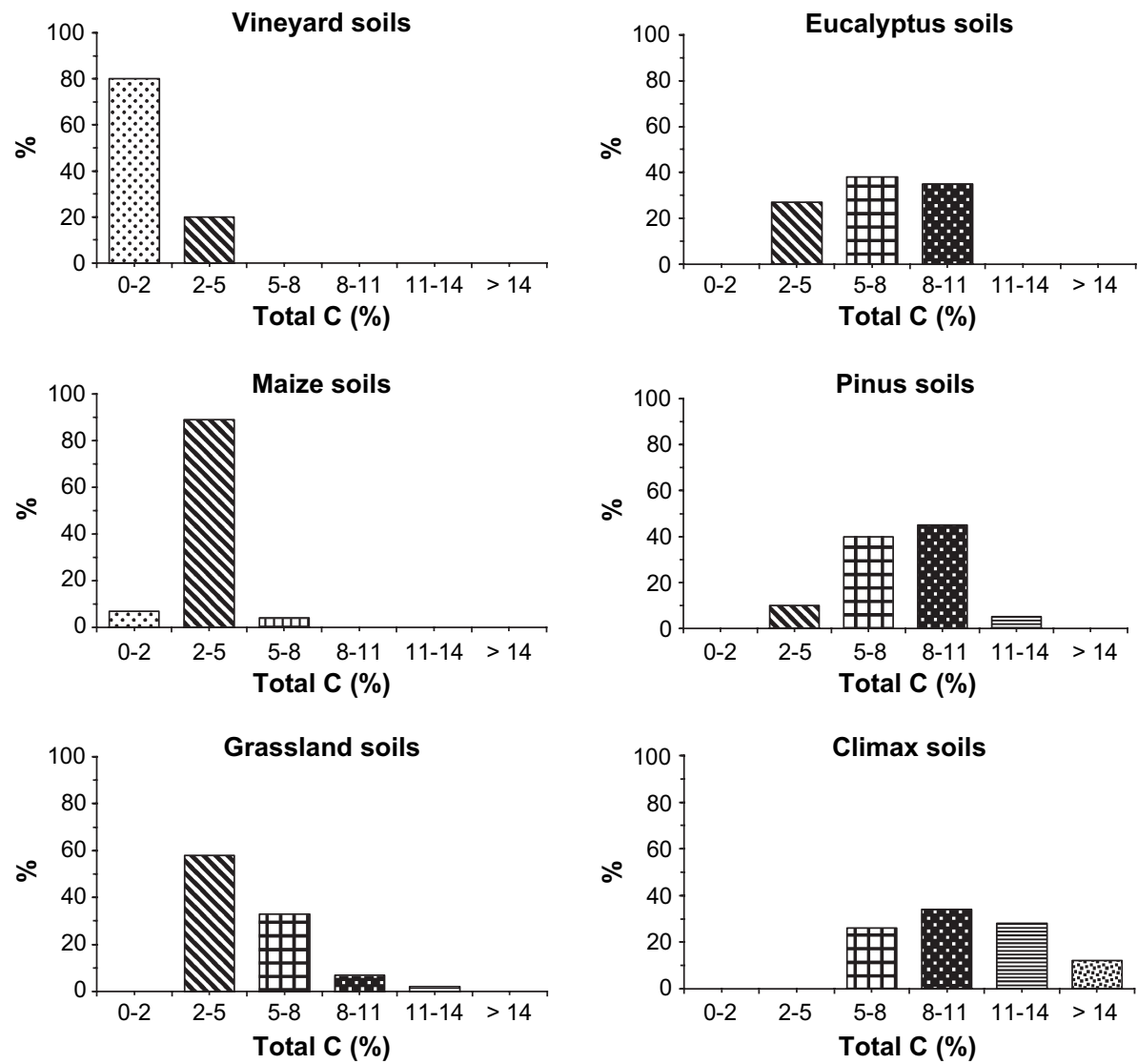

Fig. 1. Percentage frequency distribution of the soils according to their total $C$ content, for each type of use. 
Table 5

Values of enzymes activities per unit of $\mathrm{C}$, distributed according to the range of values of total C content, for soils under different types of use

\begin{tabular}{|c|c|c|c|c|c|c|c|c|c|}
\hline$\overline{C \text { range }}$ & Cellulase $/ \mathrm{C}^{\mathrm{a}}$ & Glucosid/C $\mathrm{C}^{\mathrm{b}}$ & Invertase $/ \mathrm{C}^{\mathrm{a}}$ & Casein-P/C & $\mathrm{BAA}-\mathrm{P} / \mathrm{C}^{\mathrm{d}}$ & Urease $/ C^{d}$ & Diester $/ C^{b}$ & Monoester/C & Sulph/C \\
\hline \multicolumn{10}{|c|}{ Vineyard soils } \\
\hline $0-2$ & $3.4 \pm 1.6$ & $33 \pm 17$ & $88 \pm 46$ & $18 \pm 7$ & $332 \pm 132$ & $125 \pm 31$ & $8 \pm 1$ & $91 \pm 36$ & $1.6 \pm 1.2$ \\
\hline $2-5$ & $2.0 \pm 0.1$ & $20 \pm 3$ & $71 \pm 4$ & $20 \pm 3$ & $257 \pm 31$ & $117 \pm 33$ & $8 \pm 3$ & $61 \pm 19$ & $2.3 \pm 0.8$ \\
\hline \multicolumn{10}{|c|}{ Maize soils } \\
\hline $0-2$ & $1.9 \pm 0.6$ & $35 \pm 13$ & $113 \pm 52$ & $37 \pm 11$ & $268 \pm 116$ & $182 \pm 17$ & $13 \pm 3$ & $100 \pm 51$ & $5.2 \pm 0.8$ \\
\hline $2-5$ & $3.0 \pm 2.1$ & $23 \pm 8$ & $83 \pm 25$ & $24 \pm 12$ & $223 \pm 90$ & $128 \pm 49$ & $11 \pm 5$ & $85 \pm 33$ & $4.7 \pm 1.9$ \\
\hline $5-8$ & $2.7 \pm 0.4$ & $16 \pm 2$ & $92 \pm 39$ & $21 \pm 2$ & $236 \pm 21$ & $178 \pm 37$ & $8 \pm 3$ & $55 \pm 9$ & $6.4 \pm 1.0$ \\
\hline \multicolumn{10}{|c|}{ Grassland soils } \\
\hline $2-5$ & $5.2 \pm 2.2$ & $36 \pm 13$ & $130 \pm 50$ & $29 \pm 7$ & $478 \pm 200$ & $404 \pm 196$ & $15 \pm 5$ & $112 \pm 29$ & $8.7 \pm 4.3$ \\
\hline $5-8$ & $3.9 \pm 1.5$ & $27 \pm 10$ & $133 \pm 51$ & $24 \pm 8$ & $402 \pm 179$ & $388 \pm 167$ & $12 \pm 3$ & $102 \pm 28$ & $9.6 \pm 5.0$ \\
\hline $8-11$ & $2.3 \pm 0.6$ & $23 \pm 8$ & $96 \pm 27$ & $21 \pm 3$ & $229 \pm 98$ & $207 \pm 113$ & $11 \pm 4$ & $70 \pm 14$ & $7.4 \pm 2.4$ \\
\hline $11-14$ & $2.2 \pm 1.4$ & $21 \pm 10$ & $103 \pm 43$ & $25 \pm 6$ & $199 \pm 159$ & $290 \pm 125$ & $10 \pm 4$ & $66 \pm 24$ & $6.6 \pm 3.9$ \\
\hline \multicolumn{10}{|c|}{ Eucalyptus soils } \\
\hline $2-5$ & $4.8 \pm 0.8$ & $33 \pm 21$ & $62 \pm 19$ & $21 \pm 7$ & $213 \pm 54$ & $160 \pm 54$ & $39 \pm 18$ & $159 \pm 86$ & $5.6 \pm 1.9$ \\
\hline $5-8$ & $3.7 \pm 1.2$ & $25 \pm 8$ & $62 \pm 23$ & $15 \pm 4$ & $283 \pm 124$ & $213 \pm 104$ & $22 \pm 9$ & $101 \pm 52$ & $4.8 \pm 2.2$ \\
\hline $8-11$ & $3.0 \pm 1.1$ & $24 \pm 11$ & $63 \pm 27$ & $14 \pm 7$ & $201 \pm 93$ & $146 \pm 72$ & $21 \pm 11$ & $96 \pm 41$ & $3.1 \pm 2.1$ \\
\hline \multicolumn{10}{|l|}{ Pine soils } \\
\hline $2-5$ & $3.8 \pm 1.5$ & $33 \pm 21$ & $113 \pm 42$ & $25 \pm 7$ & $312 \pm 29$ & $277 \pm 138$ & $16 \pm 7$ & $116 \pm 34$ & $5.8 \pm 1.7$ \\
\hline $5-8$ & $3.3 \pm 1.0$ & $23 \pm 9$ & $80 \pm 28$ & $18 \pm 4$ & $210 \pm 114$ & $188 \pm 98$ & $18 \pm 7$ & $104 \pm 37$ & $3.6 \pm 2.0$ \\
\hline $8-11$ & $2.6 \pm 0.8$ & $22 \pm 10$ & $76 \pm 15$ & $15 \pm 5$ & $215 \pm 98$ & $226 \pm 189$ & $22 \pm 7$ & $111 \pm 22$ & $3.9 \pm 2.0$ \\
\hline $11-14$ & $2.3 \pm 1.2$ & $25 \pm 10$ & $74 \pm 44$ & $14 \pm 1$ & $213 \pm 76$ & $252 \pm 105$ & $18 \pm 1$ & $88 \pm 10$ & $4.4 \pm 3.1$ \\
\hline \multicolumn{10}{|l|}{ Oak soils } \\
\hline $5-8$ & $2.0 \pm 0.6$ & $17 \pm 6$ & $93 \pm 20$ & $14 \pm 4$ & $167 \pm 72$ & $214 \pm 172$ & $11 \pm 5$ & $76 \pm 39$ & $6.2 \pm 2.2$ \\
\hline $8-11$ & $2.4 \pm 1.0$ & $17 \pm 9$ & $75 \pm 24$ & $11 \pm 4$ & $162 \pm 108$ & $134 \pm 75$ & $10 \pm 4$ & $57 \pm 33$ & $4.6 \pm 2.4$ \\
\hline $11-14$ & $1.9 \pm 1.0$ & $12 \pm 4$ & $53 \pm 21$ & $7 \pm 3$ & $127 \pm 79$ & $146 \pm 106$ & $9 \pm 4$ & $62 \pm 25$ & $4.2 \pm 2.1$ \\
\hline$>14$ & $2.1 \pm 0.6$ & $14 \pm 10$ & $44 \pm 13$ & $5 \pm 1$ & $131 \pm 63$ & $154 \pm 44$ & $8 \pm 5$ & $61 \pm 29$ & $3.4 \pm 1.1$ \\
\hline
\end{tabular}

a $\mu$ mol glucose ${ }^{-1} \mathrm{Ch}^{-1}$.

b $\mu$ mol $p$-nitrophenol $\mathrm{g}^{-1} \mathrm{Ch}^{-1}$.

c $\mu \mathrm{mol}$ tyrosine $\mathrm{g}^{-1} \mathrm{Ch}^{-1}$.

d $\mu \mathrm{mol} \mathrm{NH} \mathrm{N}_{3} \mathrm{~g}^{-1} \mathrm{Ch}^{-1}$.

\section{Conclusions}

Soil use causes a clear decrease in organic matter content, but enzyme activity does not always follow the same pattern and may either increase or decrease. However, irrespective of the type of land use, the values of enzyme activity per unit of carbon were always higher in soils subject to human interference than in oak soils, which indicate relative enrichment in enzymatic activity in agricultural and forest soils. Furthermore, the process of stabilization becomes more intense the greater the loss of organic matter suffered by the soil, and all enzymes are not affected in the same way, with some being more affected than others. Thus, whereas for enzymes such as arylsulphatase no enrichment occurs, for others such as proteases there is an important degree of enrichment. In other words, land use not only generates higher values of enzyme activity per unit of $C$ than in oak soils, but also greater increases in the specific activity as the $C$ content decreases, which suggests a process of enrichment of the hydrolytic enzymes in organic matter, thereby maintaining a high metabolic activity. Nevertheless, although land use modifies the enzyme activity of soils, the use of enzymes as indicators of the change in soil quality is not particularly useful because of the complexity of the observed behaviour. This complexity prevents accurate selection of the best enzyme or enzymes to use as key indicators, at least until more is known about the processes that occur as a result of change in land use. Therefore, although enzyme enrichment clearly occurs in response to land use, the data available do not enable determination of the processes involved in this enrichment. Consequently, in-depth studies of the stabilization mechanisms are required to elucidate the possible role of enzymes as indicators of soil quality.

\section{Acknowledgements}

This research was financed by the Xunta de Galicia (Project No. XUGA 40003B94) and by the Spanish Ministerio de Ciencia y Tecnología (Project No. BTE 2001-0987). The authors thank Ana I. Iglesias-Tojo, Carolina López-Cotón, Tamara Miguéns, Jorge PazFerreiro and Diana Bello for their assistance in carrying out the analyses.

\section{References}

Bandick, A.K., Dick, R., 1999. Field management effects on soil enzyme activities. Soil Biology \& Biochemistry 31, 1471-1479.

Barriuso, E., Pérez-Mateos, M., González-Carcedo, S., 1988. Actividad ureásica específica del suelo. Agrochimica 32, 284-294.

Bowman, R.A., Cole, C.V., 1978. An exploratory method for fractionation of organic phosphorus for grassland soils. Soil Science 125, 95-101.

Bowman, M.G., Tabatabai, M.A., 1978. Phosphodiesterase activity in soils. Soil Science Society of America Journal 42, 284-290.

Burns, R.G., 1978. Soil Enzymes. Academic Press, New York, 380 pp.

Burns, R.G., 1982. Enzyme activity in soil: location and possible role in microbial ecology. Soil Biology \& Biochemistry 14, 423-427.

Cao, G., Tang, Y., Mo, Y., Wang, Y., Li, Y., Zhao, X., 2004. Grazing intensity alters soil respiration in an alpine meadow of the Tibetan plateau. Soil Biology \& Biochemistry 36, 237-243.

Carter, M.R., 1986. Microbial biomass as an index for tillage-induced changes in soil microbial properties. Soil and Tillage Research 7, 29-40.

Clarholm, M., 1993. Microbial biomass P, labile P, and acid phosphatase activity in the humus layer of a spruce forest, after repeated additions of fertilizers. Biology and Fertility of Soils 16, 287-292.

Conant, R.T., Paustian, K., Elliot, E.T., 2001. Grassland management and conversion into grasslands: effects on soil carbon. Ecological Applications 11, 343-355.

Dalal, R.C., 1998. Soil microbial biomass-what do the numbers really mean? Australian Journal of Experimental Agriculture 38, 649-665.

Díaz-Fierros, F., Villar, M.C., Gil-Sotres, F., Carballas, M., Leirós, M.C., Carballas, T. Cabaneiro, A., 1988. Effect of cattle slurry fractions on nitrogen mineralization in soil. Journal of Agricultural Sciences (Cambridge) 110, 491-497. 
Dick, W.A., 1984. Influence of long-term tillage and crop rotation combinations on soil enzyme activities. Soil Science Society of America Journal 48, 569574.

Dick, R.P., 1992. A review: Long term effects of agricultural systems on soil biochemical and microbial parameters. Agriculture, Ecosystems \& Environment $40,25-36$.

Dick, R.P., 1994. Soil enzyme activities as indicators of soil quality. In: Doran, J.W. (Ed.), Defining Soil Quality for Sustainable Environment. Soil Science Society of America, Special Publication 35. SSSA-ASA, Madison, WI, pp. 107-124.

Dick, R.P., Rasmussen, P.E., Kerle, E.A., 1988. Influence of long-term residue management on soil enzyme activities in relation to soil chemical properties of a wheat-fallow system. Biology and Fertility of Soils 6, 159-164.

Dick, R.P., Sandor, J.A., Eash, N.S., 1994. Soil enzyme activities after 1500 years of terrace agriculture in the Colca Valley, Peru. Agriculture, Ecosystems \& Environment 50, 123-131.

Dilly, O., Blume, H.P., Munch, J.C., 2003. Soil microbial activities in Luvisols and Anthrosols during 9 years of region-typical tillage and fertilization practices in northern Germany. Biogeochemistry 65, 319-339.

Doran, J.W., 1980. Soil microbial and biochemical changes associated with reduced tillage. Soil Science Society of America Journal 44, 765-771.

Doran, J.W., Parkin, T.B., 1994. Defining and assessing soil quality. In: Doran, J.W., Coleman, D.C., Bezdicek, D.F., Stewart, B.A. (Eds.), Defining Soil Quality for a Sustainable Environment. Soil Science Society of America, Special Publication 35. SSSA-ASA, Madison, WI, pp. 3-21.

Doran, J.W., Sarrantonio, M., Jaure, R., 1994. Strategies to promote soil quality and health. In: Pankhurst, C.E., Doube, B.M., Gupta, V.V.S.R., Grace, P.R. (Eds.), Soil Biota: Management in Sustainable Farming Systems. CSIRO, Melbourne, pp. 230-237.

Eivazi, F., Tabatabai, M.A., 1988. Glucosidases and galactosidases in soils. Soil Biology \& Biochemistry 20, 601-606

Fedoroff, N., 1987. The production potential of soils. Part 1. Sensitivity of principal soil types to the intensive agriculture of north-western Europe. In: Barth, E., L'Hermite, P. (Eds.), Scientific Basis for Soil Protection in the European Community. Elsevier, London, pp. 65-86.

Filip, Z., 2002. International approach to assessing soil quality by ecologicallyrelated biological parameters. Agriculture, Ecosystems \& Environment 88 164-174.

García, C., Hernández, T., Costa, F., Ceccanti, B., Ciardi, C., 1992. Changes in ATP content, enzyme activity and inorganic nitrogen species during composting of organic wastes. Canadian Journal of Soil Science 72, 243-253.

Gil-Sotres, F., Trasar-Cepeda, C., Leirós, M.C., Seoane, S., 2005. Different approaches to evaluate soil quality using biochemical properties. Soil Biology \& Biochemistry 37, 877-887.

Gregorich, E.G., Carter, M.R., Angers, D.A., Monreal, C.M., Ellert, B.H., 1994. Towards a minimum data set to assess soil organic matter quality in agricultural soils. Canadian Journal of Soil Science 74, 367-385.

Guitián-Ojea, F., Carballas, T., 1976. Técnicas de análisis de suelos. Pico Sacro Editorial, Santiago de Compostela, 288 pp.

Haynes, R.J., 1999. Size and activity of the soil microbial biomass under grass and arable management. Biology and Fertility of Soils 30, 210-216.

Haynes, R.J., Tregurtha, R., 1999. Effects of increasing periods under intensive arable vegetable production on biological, chemical and physical indices of soil quality. Biology and Fertility of Soils 28, 259-266.

Haynes, R.J., Williams, P.H., 1999. Influence of stock camping behaviour on the soil microbiological and biochemical properties of grazed pastoral soils. Biology and Fertility of Soils 28, 253-258.

Holland, J.N., 1995. Effects of above-ground herbivory on soil microbial biomass in conventional and no-tillage agroecosystems. Applied Soil Ecology 2, 275279.

Islam, K.R., Weil, R.R., 2000. Land use effects on soil quality in a tropical forest ecosystem of Bangladesh. Agriculture, Ecosystems \& Environment 79, 9-16.

ISSS Working Group R.B., 1998. World Reference Base for Soil Resources: Introduction. International Society of Soil Science, International Soil Reference and Information Centre and Food and Agriculture Organization of the United Nations, Acco, Leuven, 165 pp.

Jackson, W., 2002. Natural systems agriculture: a truly radical alternative. Agriculture, Ecosystems \& Environment 88, 111-117.

Janzen, H.H., Campbell, C.A., Brandt, S.A., Lafond, G.P., Toronley-Smith, L., 1992 Light-fraction organic matter in soils from long-term crop rotations. Soil Science Society of America Journal 56, 1799-1806.

Jenkinson, D.S., 1988. The determination of microbial biomass carbon and nitrogen in soil. In: Wilson, J.R. (Ed.), Advances in Nitrogen Cycling in Agricultural Ecosystems. CAB International, Wellingford, pp. 368-386.

Jenkinson, D.S., 1990. The turnover of organic carbon in the soil. Philosophical Transactions of the Royal Society of London B 329, 361-368.

Jensen, L.S., McQueen, D.J., Sheperd, T.G., 1996. Effects of soil compaction on $\mathrm{N}$-mineralization and microbial-C and -N.I. Field measurements. Soil and Tillage Research 38, 175-188.

Kandeler, E., Eder, G., 1993. Effect of cattle slurry in grassland on microbial biomass and on activities of various enzymes. Biology and Fertility of Soils 16 249-254.

Kandeler, E., Stemmer, M., Klimanek, E.M., 1999. Response of soil microbial biomass, urease and xylanase within particle size fraction to long-term soil management. Soil Biology \& Biochemistry 31, 261-273.

Khan, A.R., 1996. Influence of tillage on soil aeration. Journal of Agronomy and Crop Science 177, 253-259.
Klein, D.A., Sorensen, D.L., Redente, E.F., 1985. Soil enzymes: A predictor of reclamation potential and progress. In: Tate, R.L., Klein, D.A. (Eds.), Soil Reclamation Processes. Microbiological Analyses and Applications. Marcel Dekker, New York, pp. 273-340.

Kuzyakov, Y., Biryukova, O.V., Kuznetzova, T.V., Mölter, K., Kandeler, E., Stahr, K., 2002. Carbon partitioning in plant and soil, carbon dioxide fluxes and enzyme activities as affected by cutting ryegrass. Biology and Fertility of Soils 35, 348-358.

Ladd, J.N., Butler, H.A., 1972. Short-term assays of soil proteolytic enzyme activities using proteins and dipeptide derivatives as substrates. Soil Biology \& Biochemistry 4, 19-30.

Ladd, J.N., Butler, J.H.R., 1975. Humus-enzyme systems and synthetic organic polymer-enzyme analogs. In: Paul, E.A., McLaren, A.J. (Eds.), Soil Biochemistry, Vol. 4. Marcel Dekker, New York, pp. 143-194.

Lal, R., Blum, W.H., Valentine, C., Stewart, B.A., 1998. Methods for Assessment of Soil Degradation. Advances in Soil Science. Lewis Publishers, Boca Raton, FL, 558 pp.

Latif, M.A., Mehuys, G.R., Mackenzie, A.F., Alli, I., Faris, M.A., 1992. Effects of legumes on soil physical quality in a maize crop. Plant and Soil 140, 15-23.

Leirós, M.C., Trasar-Cepeda, C., Seoane, S., Gil-Sotres, F., 2000. Biochemical properties of acid soils under oak vegetation (Atlantic oakwood) in an area of the European temperate-humid zone (Galicia, NW Spain): general parameters. Soil Biology \& Biochemistry 32, 733-745.

Lehninger, A.L., 1978. Bioquímica-Las bases moleculares de la estructura y la función celular, $2^{\text {a }}$ edición. Ediciones Omega, S.A, Barcelona, 1117 pp.

Lynch, J.M., Panting, L.M., 1980. Cultivation and the soil biomass. Soil Biology \& Biochemistry 12, 29-33.

Masciandaro, G., Ceccanti, B., 1999. Assessing soil quality in different agro-ecosystems through biochemical and chemico-structural properties of humic substances. Soil \& Tillage Research 51,129-137.

Mawdsley, J.L., Bardgett, R.D., 1997. Continuous defoliation of perennial ryegrass (Lolium perenne) and white clover (Trifolium repens) and associated changes in the microbial population of an upland grassland soil. Biology and Fertility of Soils 27, 969-975.

McGill, W.B., Cannon, K.R. Robertson, JA., Cook, F.D. 1986. Dynamics of soil microbial biomass and water-soluble organic $C$ in Breton $L$ after 50 years of cropping to two rotations. Canadian Journal of Soil Science 66, 1-19.

McKeague, J.A., Day, J.H., 1966. Dithionite and oxalate extractable $\mathrm{Fe}$ and $\mathrm{Al}$ as an aid in differentiating various classes of soils. Canadian Journal of Soil Science 46, $13-22$

Miguéns, T., Leirós, M.C., Gil-Sotres, F., Trasar-Cepeda, C., 2007. Biochemical properties of vineyard soils from Galicia, Spain. The Science of the Total Environment 378, 218-222.

Murphy, J., Riley, J.P., 1962. A modified single solution method for the determination of phosphate in natural waters. Analytica Chimica Acta 27, 31-36.

Nannipieri, P., Pedrazzini, F., Arcara, P.G., Piovanelli, C., 1979. Changes in amino acids, enzyme activities, and biomasses during microbial growth. Soil Science 127, 26-34.

Nannipieri, P., Ceccanti, B., Cervelli, S., Matarese, E., 1980. Extraction of phosphatases, urease, proteases, organic carbon and nitrogen from soil. Soil Science Society of America Journal 44, 1011-1016.

Nannipieri, P., Ceccanti, B., Grego, S., 1990. Ecological significance of biological activity in soil. In: Bollag, G.M., Stotzky, G. (Eds.), Soil Biochemistry, vol. 6. Marcel Dekker, New York, pp. 293-355.

Northup, B.K., Brown, J.R., Holt, J.A., 1999. Grazing impacts on the spatial distribution of soil microbial biomass around tussock grasses in a tropical grassland. Applied Soil Ecology 13, 259-270.

Nourbakhsh, F., 2007. Decoupling of soil biological properties by deforestation. Agriculture, Ecosystems \& Environment 121, 435-438.

Nuñez-Regueira, L., Rodríguez-Añón, J.A., Proupín-Castiñeras, J., NúñezFernández, O., 2006. Microcalorimetric study of changes in the microbial activity in a humic Cambisol alter reforestation with eucalyptus in Galicia (NW Spain). Soil Biology \& Biochemistry 38, 115-124.

Ogle, S.M., Breidt, F.J., Paustian, K., 2005. Agricultural management impacts on soil organic carbon storage under moist and dry climatic conditions of temperate and tropical regions. Biogeochemistry 72, 87-121.

Olander, L.P., Vitousek, P.M., 2000. Regulation of soil phosphatase and chitinase activity by $\mathrm{N}$ and $\mathrm{P}$ availability. Biogeochemistry $49,175-190$.

Perucci, P., Scarponi, L., Businelli, M., 1984. Enzyme activities in a clay-loam soil amended with various crops. Plant and Soil 81, 345-351.

Piñeiro, J., González, A., 2002. Grasslands in Galicia. In: Fisher, G., FrankowLindberg, B. (Eds.), Lowland Grasslands of Europe: Utilization and Development. FAO, Rome, Italy, p. 282.

Rasmussen, P.E., Collins, H.P., Smiley, R.E., 1989. Long-term management effects on soil productivity and crop yields in semi-arid regions of eastern Oregon. Station Bulletin 675. USDA-ARS and Oregon State University, Pendleton.

Resck, D.V.S., Vasconcellos, C.A., Vilela, L., Macedo, M.C.M., 2000. Impact of conversion of Brazilian Cerrados to cropland and pastureland on soil carbon pool and dynamics. In: Lal, R., Kimble, J.M., Stewart, B.A. (Eds.), Global Climate Change and Tropical Ecosystems. Advances in Soil Science. Lewis Publishers, Boca Raton, FL, pp. 169-196.

Saá, A., Trasar-Cepeda, C., Gil-Sotres, F., Carballas, T., 1993. Changes in soil phosphorus and acid phosphatase activity immediately following forest fires. Soil Biology \& Biochemistry 22, 511-515.

Schipper, L.A., Sparling, G.P., 2000. Performance of soil condition indicators across taxonomic groups and land uses. Soil Science Society of America Journal 64, $300-311$. 
Schinner, F., von Mersi, W., 1990. Xylanase-, CM-cellulase- and invertase activity in soils: An improved method. Soil Biology \& Biochemistry 22, 511-515.

Skujins, J.J., Braal, L., McLaren, A.D., 1962. Characterization of phosphatase in a terrestrial soil sterilized with an electron beam. Enzymologia 25, 125-133.

Sinsabaugh, R.L., Antibus, R.K., Linkins, A.E., 1991. An enzymic approach to the analysis of microbial activity during plant litter decomposition. Agriculture, Ecosystems \& Environment 34, 43-54.

Tabatabai, M.A., Bremner, J.M., 1969. Use of p-nitrophenyl phosphate for assay of soil phosphatase activity. Soil Biology \& Biochemistry 1, 301-307.

Tabatabai, M., Bremner, J.M., 1970. Arylsulphatase activity of soils. Soil Science Society of America Proceedings 34, 225-229.

Trasar-Cepeda, C., Leirós, M.C., Gil-Sotres, F., Seoane, S., 1998. Towards a biochemical quality index for soils: An expression relating several biological and biochemical properties. Biology and Fertility of Soils 26, 100-106.

Trasar-Cepeda, C., Leirós, M.C., Gil-Sotres, F., 2000. Biochemical properties of acid soils under oak vegetation (Atlantic oakwood) in an area of the European temperate-humid zone (Galicia, NW Spain): specific parameters. Soil Biology \& Biochemistry $32,747-755$.

Trasar-Cepeda, C., Leirós, M.C., García-Fernández, F., Gil-Sotres, F., 2003. Biochemical properties of the soils of Galicia (NW Spain): Their use as indicators of soil quality. In: García, C., Hernández, M.T. (Eds.), Research and Perspectives of Soil Enzymology in Spain. CEBAS-CSIC, pp. 175-206.

Trasar-Cepeda, C., Gil-Sotres, F., Leirós, M.C., 2007. Thermodynamic parameters of enzymes in grassland soils of Galicia, NW Spain. Soil Biology and Biochemistry 39, 311-319.

Trasar-Cepeda, C., Leirós, M.C., Seoane, S., Gil-Sotres, F., 2008. Biochemical properties of soils under crop rotation. Applied Soil Ecology 39, 133-143.

Vance, E.D., Brookes, P.C., Jenkinson, D.S., 1987. An extraction method for measuring soil microbial biomass C. Soil Biology \& Biochemistry 19, 703-707.

Visser, S., Parkinson, D., 1992. Soil biological criteria as indicators of soil quality: soil microorganisms. American Journal of Alternative Agriculture 7, 33-37.

Wardle, D.A., Barker, G.M., 1997. Competition and herbivory in establishing grassland communities: Implications for plant biomass, species diversity and soil microbial activity. Oikos 80, 470-480.

Yakovchenko, V.I., Sikora, L.J., Rauffman, D.D., 1996. A biologically based indicator of soil quality. Biology and Fertility of Soils 21, 245-251.

Zacheis, A., Ruess, R.W., Hupp, J.W., 2002. Nitrogen dynamics in an Alaskan salt marsh following spring use by geese. Oecologia 130, 600-608.

Zinn, Y.L., Resck, D.V.S., da Silva, J.E., 2002. Soil organic carbon as affected by afforestation with Eucalyptus and Pinus in the Cerrado region of Brazil. Forest Ecology and Management 166, 285-294. 